\title{
Multielement Contamination of Land in the Margin of Highways
}

\author{
Dimitrios E. Alexakis
}

Citation: Alexakis, D.E.

Multielement Contamination of Land in the Margin of Highways. Land 2021, 10, 230. https://doi.org/ 10.3390/land 10030230

Received: 27 January 2021

Accepted: 22 February 2021

Published: 25 February 2021

Publisher's Note: MDPI stays neutral with regard to jurisdictional claims in published maps and institutional affiliations.

Copyright: (C) 2021 by the author. Licensee MDPI, Basel, Switzerland. This article is an open access article distributed under the terms and conditions of the Creative Commons Attribution (CC BY) license (https:/ / creativecommons.org/licenses/by/ $4.0 /)$.
Laboratory of Geoenvironmental Science and Environmental Quality Assurance, Department of Civil Engineering, School of Engineering, University of West Attica, 250 Thivon \& P.Ralli Str, 12244 Athens, Greece; d.alexakis@uniwa.gr; Tel.: +30-210-5381256

\begin{abstract}
The spatial distribution of potentially toxic elements in land near a heavily loaded highway in the West Attica region (Greece) is discussed. This study aimed to investigate the extent of soil contamination with trace elements on land in the margin of highways. The concentration of thirtyfive elements in topsoil, car ash, and road sediment bulk samples was determined. Statistical and spatial analysis was applied for evaluating the geochemical dispersion of the examined elements. Geo-accumulation index was estimated. Elements content were compared to criteria and screening values established by the literature. The concentration of $\mathrm{As}, \mathrm{Cu}, \mathrm{Mn}, \mathrm{Ni}, \mathrm{P}, \mathrm{Pb}$, and $\mathrm{Zn}$ in topsoil appeared to be influenced by traffic emissions. It is found that engine exhaust, tyre wear, and brake lining contribute to the $\mathrm{As}, \mathrm{Ba}, \mathrm{Cu}, \mathrm{Mn}, \mathrm{Ni}, \mathrm{P}, \mathrm{Pb}$, and $\mathrm{Zn}$ content recorded in topsoil in the margin of highways. The bulk sample of road sediment is moderately contaminated to extremely contaminated with $\mathrm{Cu}, \mathrm{Mn}, \mathrm{Ni}, \mathrm{P}, \mathrm{Pb}$, and $\mathrm{Zn}$. Comparison of elements content in topsoil with screening values revealed that $\mathrm{Al}, \mathrm{As}, \mathrm{B}, \mathrm{Ba}, \mathrm{Cd}, \mathrm{Co}, \mathrm{Cr}, \mathrm{Cu}, \mathrm{Fe}, \mathrm{Mn}, \mathrm{Ni}, \mathrm{Sb}, \mathrm{V}$, and $\mathrm{Zn}$ pose a potential risk for plants.
\end{abstract}

Keywords: trace elements; traffic emissions; soil; car ash; road sediment; geo-accumulation index; West Attica

\section{Introduction}

The intensification of the movement of cars and trucks cause the emission of particles containing trace elements that can have a negative impact on soil and air quality [1-3]. Road sediment consists of both anthropogenic and natural particles. The element concentration in the soil in the vicinity of a motorway is mainly controlled by [3-10]: (a) mineral particles formed by the weathering of soils; (b) particles emitted from cars and trucks; and (c) airborne pollution from various sources (e.g., by industrial activities).

The tracking of the trace element's source in road sediments is critical for controlling pollution and applying measures for protecting human health and ecosystems. Additionally, trace elements in road sediment and soil can migrate long-distance and enter the water resources [4-6]. The sources of particles emitted from traffic are mainly [3,11]: (a) trace elements used to supplement fuels, oils, and lubricants (e.g., Cd, Cu, Ni, Zn); (b) material produced by the wearing of asphalt pavement; (c) leakage from vehicle batteries and damaged tanks; and (d) material produced by the wearing of automobile tyres, clutch disks and brake pads; and (e) emissions from incomplete combustion products of motor fuel. Moreover, road sediment is considered the most important pollutant carrier on urban roads [12,13]. Traffic turbulence in dry periods or airflow created by wind can easily remobilize and transport the road sediments and trace elements into the atmosphere. According to Hong et al. [12], vehicle exhaust related sources contributed high amounts of trace elements even though they only accounted for less than $10 \%$ of the mass in road sediment. Moreover, Hong et al. [12] estimated that the ratio of the mass of road sediment deposited from heavy-duty vehicle: light-duty vehicle was 1:50. 
The main objectives of this study are: (a) to evaluate the variation in the concentration of elements in the topsoil samples collected close to highways; and (b) to record the impact of traffic emissions in the land in the margin of highways.

\section{Materials and Methods}

\subsection{Area Studied}

The study area is located in the West Attica region, about $50 \mathrm{~km}$ west of Athens, Greece (Figure 1). The area studied extends from Saronic Gulf in the south to the Geraneia Mountain in the north and included the city of Kineta. The study area is characterized by hilly relief. The dominant plant community in the area studied is Pinus halepensis, while most cultivated plants are primarily olive trees followed by vegetables.

A severe wildfire event occurred on 23 July 2018 in the Kineta area, which damaged several vehicles and buildings and caused the evacuation of the Kineta area while burning hundreds of hectares of forest and suburban area [14,15]. The residential area of Kineta is a popular holiday destination. It has the characteristics of suburbs adjacent to two heavily loaded motorways (mainly small vehicles, light trucks, medium trucks, and heavy trucks). Major highways 1 and 2 are among the most important national traffic roads in Greece, which connects Athens, the capital of Greece, with the southernmost part of mainland Greece, the Peloponnese peninsula (Figure 1). Highway 1 is a major and modern motorway that is a part of the National Road Athens-Korinthos and serves as the main link between the Attica Region and the Peloponnese Region. Highway 1 has a total of three traffic lanes in each direction. The total transactions in National Road Athens-Korinthos were 49.573.761 in 2018 [16]. Highway 2 is a major motorway that is a part of the oldest National Road Athens-Korinthos (Palaia Ethniki Odos), which also connects the Attica Region with the southernmost part of mainland Greece, the Peloponnese peninsula.

In the studied area, the following geological formations outcrop [17-21]: marly formations with manganese oxides, marls, conglomerates, sandstones, limestones, dolomites, serpentinites, manganese ore deposits, schists, peridotite bodies, and volcanic rocks. Relevant literature sources were applied to gather soil quality data of the study area [14,15].

The study area's meteorological data is obtained from the meteorological station of the National Observatory of Athens at Agioi Theodoroi (Lat: $38 \mathrm{deg} 00 \mathrm{~min}$, Long: $23 \mathrm{deg}$ $06 \mathrm{~min}$, Elevation $37 \mathrm{~m}$ ) [22]. The average annual rainfall in the year 2019 was $644.4 \mathrm{~mm}$, and the number of rainy days with rain over $2 \mathrm{~mm}$ was 57 [23]. The dominant wind in the study area is from the direction of WNW (Figures 1 and 2) [23].
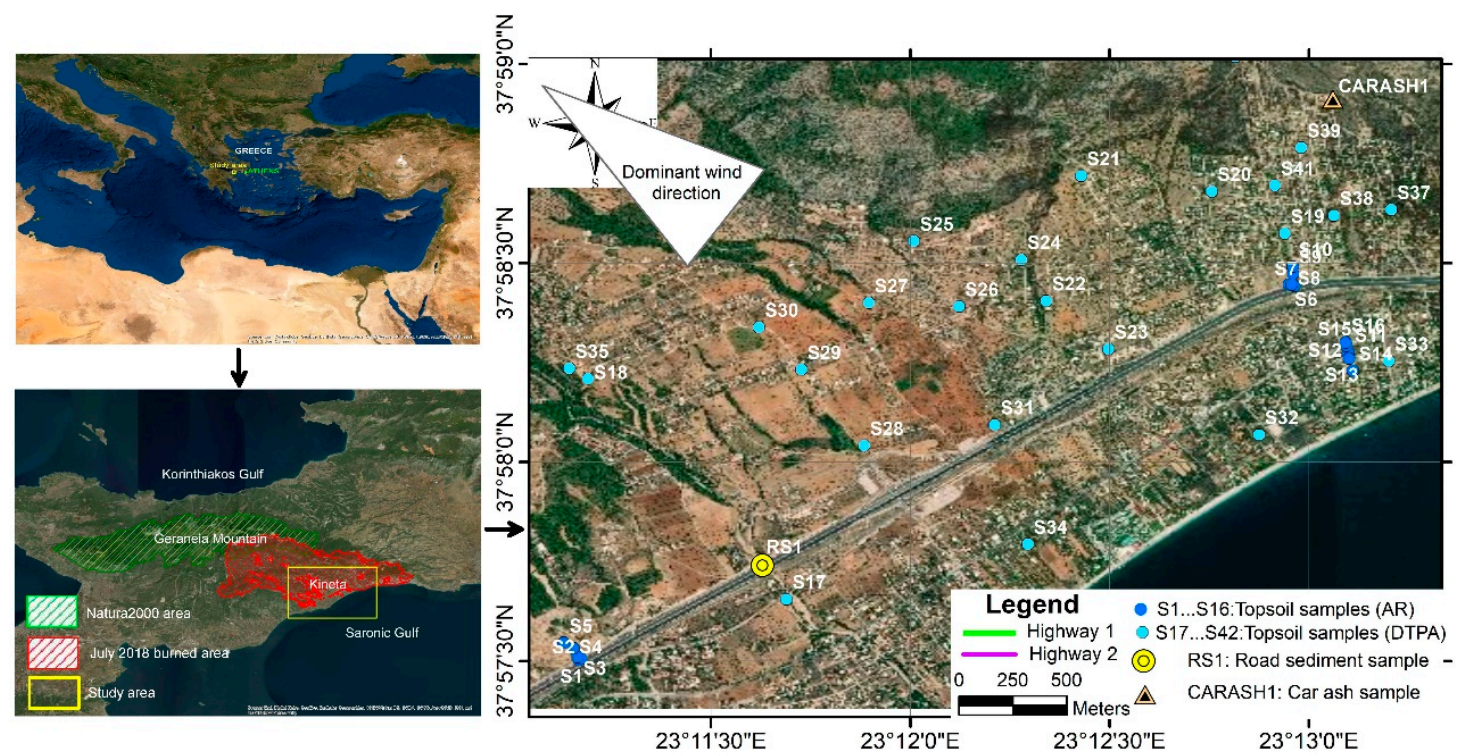

Figure 1. Google Earth ${ }^{\circledR}$ image (December 2020) showing the area studied, Natura 2000 area, wildfire impacted area, sampling locations, dominant wind direction [23], and the highways. 


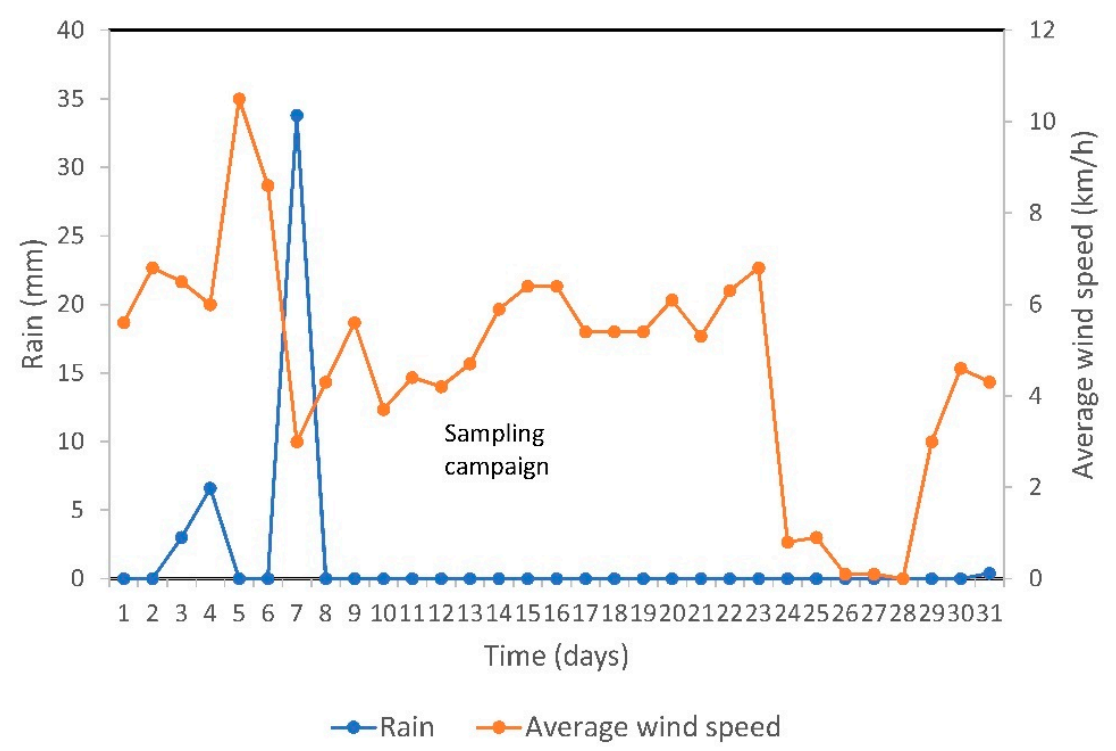

Figure 2. Rainfall, average wind speed for October 2019, and date of sampling campaign (The data of this plot was obtained from the meteorological station of the National Observatory of Athens at Agioi Theodoroi [22,23]).

\subsection{Fieldwork, Collection and Preparation of Samples}

The sampling campaign was conducted on 15 and 16 October 2019. Metal-free tools were applied for the collection of samples. A Spectra Precision Geographical Positioning System with an Ashtech Global Navigation Satellite System Receiver (Trimble, Spectra, Westminster, CO, USA) was used for recording the geographical coordinates of sampling sites. The topsoil ( $0-5 \mathrm{~cm}$ depth) samples were gathered using a polypropylene shovel after removing the superficial debris. Each collected topsoil sample is the composite of five subsamples over a $1 \mathrm{~m}^{2}$ patch of land. Then, topsoil subsamples were homogenized into a single bulk sample (about $1 \mathrm{~kg}$ ). Each topsoil sample was stored in a clean plastic bag. Topsoil samples (S1-S16) were collected from three transects at Highway 1 and 2 (Figure 1). Each transect was typically sampled at pre-determined intervals of $0 \mathrm{~m}, 10 \mathrm{~m}, 20 \mathrm{~m}, 50 \mathrm{~m}$, and $100 \mathrm{~m}$. During the sampling campaign, it was impossible to apply the transect method in any other site of the study area because of buildings and private properties surrounded by fences. Topsoil samples (S17-S42) were gathered from sites north and south of the highways. The sampling site for road sediment of Highway 1 was selected due to its ease and safety of access, which facilitated the collection of the bulk sample. To reduce the effect of point-like sources of pollution, the road sediment (bulk-sample) was the composite of ten subsamples of dry sediment. The bulk sample of road sediment was collected from the edges of Highway 1 by sweeping a nearly $4 \mathrm{~m}^{2}$ area using a plastic brush and a dustpan (Figure 1). The last rainfall event, which may have influenced the availability of elements on the road sediment, has been recorded seven days earlier than the sampling campaign, meaning that the accumulation time of road sediment is seven days (Figure 2). The sampling road site was flat and paved with asphalt. The bulk sample of car ash was gathered from the residential area of Kineta. Many burned cars have been removed from the wildfire impacted area, but at the sampling site CARASH1 (Figure 1), the damaged car and amount of ashes were found during the field survey. The bulk sample of car ash was the result of the composition of six subsamples of car ash found at the front and back parts of the small car (two different sides next to the car wheels) and the middle part of the vehicle (two different sides between the front and back door) (Figure S1). The lack of data related to the chemical composition of ash derived by automobiles, particularly concerning the trace elements content, poses significant difficulties in delineating elements' source. Thus, the chemical analysis of the bulk sample of car ash found at the sampling site CARASH1 provides a suggestion about the origins of trace elements content in topsoil 
and bulk sample of road sediment of the study area. The sampling procedures applied in this study were given in more detail by Alexakis et al. [14] and Alexakis [24].

\subsection{Laboratory Treatment}

The collected topsoil (S1-S42), road sediment, and car ash samples were dried at room temperature $\left(<20^{\circ} \mathrm{C}\right)$ for ten days and then sieved using a nylon screen of $2 \mathrm{~mm}$ and $0.2 \mathrm{~mm}$ and stored in clean plastic bags. The homogenised $<0.2 \mathrm{~mm}$ soil fraction was used for further treatment. Topsoil samples S1 to S16, bulk sample road sediment, and a bulk sample of car ash were digested with an aliquot of the aqua-regia acid solution $\left(\mathrm{HCl}: \mathrm{HNO}_{3}\right.$, 3:1 $v / v)$, and the supernatants were used for the measurement of $\mathrm{Ag}, \mathrm{Al}, \mathrm{As}, \mathrm{B}, \mathrm{Ba}, \mathrm{Be}, \mathrm{Bi}$, $\mathrm{Ca}, \mathrm{Cd}, \mathrm{Co}, \mathrm{Cr}, \mathrm{Cu}, \mathrm{Fe}, \mathrm{Ga}, \mathrm{Hg}, \mathrm{K}, \mathrm{La}, \mathrm{Mg}$, Mn, Mo, Na, Ni, P, Pb, S, Sb, Sc, Sr, Th, Ti, Tl, $\mathrm{U}, \mathrm{V}, \mathrm{W}$, and $\mathrm{Zn}$ by inductively coupled plasma-atomic emission spectrometry (ICP-AES). Topsoil samples S17 to S42 were digested with DTPA (Diethylene-Triamine-Penta-Acetic acid) extraction method, and the supernatants were analysed for $\mathrm{Cu}, \mathrm{Fe}, \mathrm{Zn}$, and $\mathrm{Mn}$ by atomic absorption spectrometry (AAS). DTPA is a standard reagent applied to evaluate the concentration of mobile fraction of metals in soils [25-28]; while Wuana and Okieimen [28] reported that heavy metals in the soil from anthropogenic sources (e.g., traffic emissions) tend to be more mobile than forms of lithogenic or pedogenic origin. The Montana Soil Reference Materials (SRM) SRM 2710 and SRM 2711 obtained from the Nationals Institute of Standards and Technology as well as in-house soil reference materials were applied for analytical quality control (accuracy $<10 \%$ ). The sequence of chemical analysis was repeated in duplicate (precision 10\%).

\subsection{Statistical and Spatial Analysis}

Statistical analysis is applied to study the geochemical data distribution in the vicinity of highways of the Kineta area. For all statistical work, the software codes Microsoft ${ }^{\circledR}$ Excel (Redmond, Washington, DC, USA) and IBM ${ }^{\circledR}$ SPSS 26.0 for Windows (International Business Machines Corporation; Statistical Product and Service Solutions; Armonk, NY, USA) were applied. The Geo-accumulation index ( Igeo $_{\text {ge }}$, initially defined by Müller [29], is used by many researchers [30-32] to discriminate the influence of traffic emissions on the element's content in topsoil in the margin of highways. In other words, $\mathrm{I}_{\text {geo }}$ is used to normalize the observed element content by reducing regional geological variations $[33,34]$. The $I_{g e o}$ approach has been widely applied in various sites by many researchers $[6,33-36]$. The addition of the source of atmospheric deposition would further enhance the discussion of this study's findings, leading to a more accurate explanation of the trace elements content observed in the vicinity of highways. The normalized index of geoaccumulation $\left(\mathrm{I}_{\text {geo }}\right)$ proposed by $\mathrm{Xu}$ et al. [6], which normalizes contaminants content using the ratio between the metal and the normalizing element, can be applied in this study. It is computed using the following equation:

$$
\mathrm{I}_{\text {geo }}=\log _{2}\left[\frac{\left(\frac{\mathrm{C}_{\mathrm{m}}}{\mathrm{Sc}}\right)_{\text {sample }}}{\left(\frac{1.5 \times \mathrm{B}_{\mathrm{m}}}{\mathrm{Sc}}\right)_{\text {background }}}\right]
$$

where $C_{m}$ is the measured concentration of element $m ; B_{m}$ is the content of element $\mathrm{m}$ in "average shale" [37]; and 1.5 is the background matrix correction factor. Xu et al. [6] proposed $\mathrm{Al}$ as the normalizing element because its relative proportion to other elements is supposed to be constant; while Kim et al. [33] adopted Sc as the reference element to standardize all the calculations. For this study, Sc is applied as the normalizing element. The classes of geoaccumulation index varying between uncontaminated and extremely contaminated as follows [29]: $\mathrm{I}_{\text {geo }} \leq 0$, practically uncontaminated; $0<\mathrm{I}_{\text {geo }}<1$, uncontaminated to moderately contaminated; $1<\mathrm{I}_{\text {geo }}<2$, moderately contaminated; $2<\mathrm{I}_{\text {geo }}$ $<3$ moderately to heavily contaminated; $3<\mathrm{I}_{\text {geo }}<4$, heavily contaminated; $4<\mathrm{I}_{\text {geo }}<5$, heavily to extremely contaminated; $5<\mathrm{I}_{\mathrm{geo}}$, extremely contaminated. 
Spatial analysis was carried out using the software code ArcView 10.4 GIS (ESRI ${ }^{\circledR}$ ) (Environmental Systems Research Institute; Redlands, CA, USA). The location of sampling sites was inserted as a separate layer in the GIS database. The element concentration in the examined samples are compared against the most current regulations and standards given from the Environmental Protection Agency (EPA) [38] and the Canadian Council of Ministers of the Environment (CCME) [39].

\section{Results and Discussion}

\subsection{Elements Content in Sampled Media of the Study Area}

Table 1 tabulates the median value of the element content of the examined samples. The Ag, Bi, Ga, Hg, Mo, Th, Tl, U, and $\mathrm{W}$ presented concentrations below the analytical method's corresponding detection limit (Table 1). The topsoil in the study area had been classified as sandy loam $(46.2 \%)$, sandy clay loam $(23.1 \%)$, loamy sand $(7.7 \%)$, clay loam $(7.7 \%)$, loam $(7.7 \%)$, and sandy clay $(7.7 \%)$ textures [14]. Topsoil samples presented nearneutral conditions, varying between 7.12 and 7.83 [14]. Median values of CEC (Cation Exchange Capacity), EC (Electric Conductivity), and OM (Organic Matter) for topsoil of the area studied are $31.94 \mathrm{cmol}(+) \mathrm{kg}^{-1}, 2,725 \mu \mathrm{S} \mathrm{cm}^{-1}, 13.94 \%$, respectively [14].

The median value of major elements in topsoil samples S1-S16 (aqua regia treated samples) from highest to lowest were: $\mathrm{Ca}(22.30 \%)>\mathrm{Mg}(4.15 \%)>\mathrm{Fe}(1.49 \%)>\mathrm{Al}(0.88 \%)$ $>\mathrm{K}(0.19 \%)>\mathrm{S}(0.07 \%)>\mathrm{Na}(0.03 \%)>\mathrm{Ti}(0.01 \%)$. Other elements that followed were in the order: $\mathrm{P}>\mathrm{Mn}>\mathrm{Ni}>\mathrm{Sr}>\mathrm{Cr}>\mathrm{Zn}>\mathrm{Ba}>\mathrm{Pb}>\mathrm{V}>\mathrm{Cu}>\mathrm{As}>\mathrm{Co}>\mathrm{B}>\mathrm{La}>\mathrm{Sb}>\mathrm{Sc}>$ $\mathrm{Be}>\mathrm{Cd}$ (Table 1). The median value of $\mathrm{Ba}, \mathrm{Fe}, \mathrm{Mn}$, and $\mathrm{Sc}$ in topsoil samples of the area studied is lower than the European's median value of $65 \mathrm{mg} \mathrm{kg}^{-1}, 1.96 \%, 382 \mathrm{mg} \mathrm{kg}^{-1}$, and $8.21 \mathrm{mg} \mathrm{kg}^{-1}$, respectively, i.e., the median value derived from soil geochemical surveys throughout Europe which may serve as background value of uncontaminated soil provided by Salminen et al. [40]. The median value of $\mathrm{As}, \mathrm{Cd}, \mathrm{Co}, \mathrm{Cr}, \mathrm{Cu}, \mathrm{Ni}, \mathrm{Pb}$, $\mathrm{Sb}, \mathrm{Sr}$, and $\mathrm{Zn}$ in topsoil samples of the study area is higher than the European's median value (in mg kg${ }^{-1}$ ) of $6.00,0.145,7.0,22.0,12.0,14.0,15.0,0.60,89.0$, and 48.0, respectively. The observed content of $\mathrm{Co}, \mathrm{Cr}, \mathrm{Mn}$, and $\mathrm{Ni}$ in the topsoil should be attributed mainly to geogenic sources: the peridotites and serpentinites of the broader area. Similar findings, including that peridotites and serpentinites are considered as the primary source of $\mathrm{Co}$, $\mathrm{Cr}, \mathrm{Mn}$, and $\mathrm{Ni}$ for the enrichment in the soil of the area studied, are also reported by Alexakis [15]. Moreover, Alexakis [15] observed median values (in $\mathrm{mg} \mathrm{kg}^{-1}$ ) of As (9), $\mathrm{Cd}$ (0.80), Co (7.0), Cr (51.0), Cu (39), Mn (453.0), Ni (91.0), Pb (78.0), and Zn (295.0) in wildfire ash, suggesting that ash is an additional source of these elements in soil of the study area. The median content of elements in topsoil samples S17-S42 (DTPA treated samples) from highest to lowest were: $\mathrm{Mn}\left(21.62 \mathrm{mg} \mathrm{kg}^{-1}\right)>\mathrm{Fe}(0.0016 \%)>\mathrm{Zn}\left(5.15 \mathrm{mg} \mathrm{kg}^{-1}\right)>$ $\mathrm{Cu}\left(1.22 \mathrm{mg} \mathrm{kg}^{-1}\right)$. Davies [41] reported airborne pollution as an important source of $\mathrm{Pb}$ for topsoil and that the total atmospheric deposition of $\mathrm{Pb}$ in the topsoil of pristine areas varies between 3.1 and $31 \mathrm{mg} \mathrm{m}^{-2}$ year $^{-1}$. In contrast, in industrial and suburban areas, it rises to $27-140 \mathrm{mg} \mathrm{m}^{-2}$ year $^{-1}$ [41]. Although $\mathrm{Pb}$ is not used in modern times as an additive to gasoline, it is a very persistent element that can be found in topsoil in the neighborhood of highways due to the past use of $\mathrm{PbO}_{4}$. The $\mathrm{Pb}$ content in gasoline ranged from 0.6 to $0.7 \mathrm{~g} \mathrm{~L}^{-1}$ [42]. Furthermore, Romic et al. [43], who studied the distribution of heavy metals in topsoil in the vicinity of highways of the city of Zagreb (Croatia), reported that the recorded $\mathrm{Cd}, \mathrm{Ni}, \mathrm{Pb}$, and $\mathrm{Zn}$ anomalous content could be attributed mainly to traffic emissions. Wiseman et al. [44] recorded an increase in As (5.5 mg kg-1), Co (11 mg $\left.\mathrm{kg}^{-1}\right), \mathrm{Cr}\left(48 \mathrm{mg} \mathrm{kg}^{-1}\right), \mathrm{Ni}\left(22 \mathrm{mg} \mathrm{kg}^{-1}\right)$, and $\mathrm{Pb}\left(12 \mathrm{mg} \mathrm{kg}^{-1}\right)$ content in roadside soil in Toronto (Canada), which can be explained by the traffic inputs, and also stated that this does not mean that other elements emitted from traffic are not accumulating in the roadside environment. Besides, Alexakis [15] reported a spatial correlation between high $\mathrm{Pb}$ content (up to $140 \mathrm{mg} \mathrm{kg}^{-1}$ ) in wildfire ash and the neighborhood of Highway 1, also suggesting the anthropogenic origin of $\mathrm{Pb}$. 
Table 1. Limits of analytical detection, the median value of elements concentration in topsoils, road sediment bulk sample, and car ash bulk sample gathered from the sampling sites compared to the corresponding level provided from the literature.

\begin{tabular}{|c|c|c|c|c|c|c|c|c|c|c|}
\hline & & & \multicolumn{4}{|c|}{ Sample Type } & \multicolumn{2}{|c|}{ EPA [38] } & \multicolumn{2}{|c|}{ CCME [39] } \\
\hline & & & ${ }^{(\mathrm{AR})}$ Topsoil & ${ }^{(\mathrm{DTPA})}$ Topsoil & $\begin{array}{l}(\mathrm{AR}) \text { Road } \\
\text { sediment }\end{array}$ & $\begin{array}{l}{ }^{(\mathrm{AR})} \mathrm{Car} \\
\text { ash }\end{array}$ & RS & P,A,M & $\mathrm{A}$ & $\mathrm{R}$ \\
\hline $\mathrm{n}$ & & & 16 & 26 & 1 & 1 & & & & \\
\hline \multirow[t]{2}{*}{$\begin{array}{l}\text { Sample } \\
\text { Code }\end{array}$} & & & S1-S16 & S17-S42 & RS1 & CARASH1 & & & & \\
\hline & Units & $\mathrm{DL}$ & Median (SD) & & & & & & & \\
\hline $\mathrm{Ag}$ & $\mathrm{mg} \mathrm{kg}^{-1}$ & 0.2 & n.d. & n.d. & n.d. & n.d. & n.v. & n.v. & n.v. & n.v. \\
\hline $\mathrm{Al}$ & $\%$ & 0.01 & $0.88(0.25)$ & n.d. & 0.82 & 1.83 & 0.77 & 0.005 & n.v. & n.v. \\
\hline As & $\mathrm{mg} \mathrm{kg}^{-1}$ & 2 & $13.5(13.3)$ & n.d. & 8 & 6 & 0.68 & 5.7 & 12 & 12 \\
\hline B & $\mathrm{mg} \mathrm{kg}^{-1}$ & 10 & $10(2.5)$ & n.d. & 10 & 10 & 1600 & 0.5 & n.v. & n.v. \\
\hline $\mathrm{Ba}$ & $\mathrm{mg} \mathrm{kg}^{-1}$ & 10 & $50(15.2)$ & n.d. & 150 & 930 & 1500 & 1.04 & 750 & 500 \\
\hline $\mathrm{Be}$ & $\mathrm{mg} \mathrm{kg}^{-1}$ & 0.5 & $0.5(0.1)$ & n.d. & n.d. & 0.5 & 16 & 1.06 & n.v. & n.v. \\
\hline $\mathrm{Bi}$ & $\mathrm{mg} \mathrm{kg}^{-1}$ & 2 & n.d. & n.d. & n.d. & n.d. & n.v. & n.v. & n.v. & n.v. \\
\hline $\mathrm{Ca}$ & $\%$ & 0.01 & $22.30(2.72)$ & n.d. & 17.4 & 14 & n.v. & n.v. & n.v. & n.v. \\
\hline $\mathrm{Cd}$ & $\mathrm{mg} \mathrm{kg}^{-1}$ & 0.5 & $0.25(0.15)$ & n.d. & 0.5 & 15.7 & 7.1 & 0.00222 & 1.4 & 10 \\
\hline $\mathrm{Co}$ & $\mathrm{mg} \mathrm{kg}^{-1}$ & 1 & $11(61.9)$ & n.d. & 21 & 283 & 2.3 & n.v. & 40 & 50 \\
\hline $\mathrm{Cr}$ & $\mathrm{mg} \mathrm{kg}^{-1}$ & 1 & 79 (202) & n.d. & 311 & 55 & 12000 & $0.4 *$ & 64 & 64 \\
\hline $\mathrm{Cu}$ & $\mathrm{mg} \mathrm{kg}^{-1}$ & 1 & $17(7)$ & $1.22(0.58)$ & 97 & 1200 & 310 & 5.4 & 63 & 63 \\
\hline $\mathrm{Fe}$ & $\%$ & 0.01 & $1.49(1.50)$ & $\begin{array}{l}0.0016 \\
(0.00074)\end{array}$ & 2.78 & 1.37 & 0.55 & 0.02 & n.v. & n.v. \\
\hline $\mathrm{Ga}$ & $\mathrm{mg} \mathrm{kg}^{-1}$ & 10 & n.d. & n.d. & n.d. & n.d. & n.v. & n.v. & n.v. & n.v. \\
\hline $\mathrm{Hg}$ & $\mathrm{mg} \mathrm{kg}^{-1}$ & 1 & n.d. & n.d. & n.d. & n.d. & n.v. & n.v. & n.v. & n.v. \\
\hline K & $\%$ & 0.01 & $0.19(0.06)$ & n.d. & 0.16 & 0.09 & n.v. & n.v. & n.v. & n.v. \\
\hline $\mathrm{La}$ & $\mathrm{mg} \mathrm{kg}^{-1}$ & 10 & $5(4)$ & n.d. & 10 & 10 & n.v. & n.v. & n.v. & n.v. \\
\hline $\mathrm{Mg}$ & $\%$ & 0.01 & $4.15(2.30)$ & n.d. & 3.35 & 9.98 & n.v. & n.v. & n.v. & n.v. \\
\hline $\mathrm{Mn}$ & $\mathrm{mg} \mathrm{kg}^{-1}$ & 5 & $280.5(93.7)$ & $21.62(11.59)$ & 947 & 311 & 180 & 100 & n.v. & n.v. \\
\hline Mo & $\mathrm{mg} \mathrm{kg}^{-1}$ & 1 & n.d. & n.d. & n.d. & n.d. & n.v. & n.v. & n.v. & n.v. \\
\hline $\mathrm{Na}$ & $\%$ & 0.01 & $0.03(0.01)$ & n.d. & 0.08 & 0.04 & n.v. & n.v. & n.v. & n.v. \\
\hline $\mathrm{Ni}$ & $\mathrm{mg} \mathrm{kg}^{-1}$ & 1 & $163.5(516)$ & n.d. & 535 & 67 & 150 & 13.6 & 50 & 50 \\
\hline $\mathrm{P}$ & $\mathrm{mg} \mathrm{kg}^{-1}$ & 10 & $525(598)$ & n.d. & 1160 & 630 & n.v. & n.v. & n.v. & n.v. \\
\hline $\mathrm{Pb}$ & $\mathrm{mg} \mathrm{kg}^{-1}$ & 2 & $21.5(11.7)$ & n.d. & 46 & 199 & 400 & 0.0537 & 70 & 140 \\
\hline$S$ & $\%$ & 0.01 & $0.07(0.03)$ & n.d. & 0.11 & 0.26 & n.v. & 0.0002 & n.v. & n.v. \\
\hline $\mathrm{Sb}$ & $\mathrm{mg} \mathrm{kg}^{-1}$ & 2 & $2(0.5)$ & n.d. & 7 & 10 & 3.1 & 0.142 & n.v. & n.v. \\
\hline Sc & $\mathrm{mg} \mathrm{kg}^{-1}$ & 1 & $2(2.6)$ & n.d. & 3 & 1 & n.v. & n.v. & n.v. & n.v. \\
\hline $\mathrm{Sr}$ & $\mathrm{mg} \mathrm{kg}^{-1}$ & 1 & $111(35)$ & n.d. & 132 & 135 & 4700 & n.v. & n.v. & n.v. \\
\hline Th & $\mathrm{mg} \mathrm{kg}^{-1}$ & 20 & n.d. & n.d. & n.d. & n.d. & n.v. & n.v. & n.v. & n.v. \\
\hline $\mathrm{Ti}$ & $\%$ & 0.01 & $0.01(0.01)$ & n.d. & 0.03 & 0.06 & n.v. & n.v. & n.v. & n.v. \\
\hline $\mathrm{Tl}$ & $\mathrm{mg} \mathrm{kg}^{-1}$ & 10 & n.d. & n.d. & n.d. & n.d. & n.v. & n.v. & n.v. & n.v. \\
\hline $\mathrm{U}$ & $\mathrm{mg} \mathrm{kg}^{-1}$ & 10 & n.d. & n.d. & n.d. & n.d. & n.v. & n.v. & n.v. & n.v. \\
\hline $\mathrm{V}$ & $\mathrm{mg} \mathrm{kg}^{-1}$ & 1 & $21.5(14)$ & n.d. & 35 & 10 & 39 & 1.59 & n.v. & n.v. \\
\hline W & $\mathrm{mg} \mathrm{kg}^{-1}$ & 10 & n.d. & n.d. & n.d. & n.d. & n.v. & n.v. & n.v. & n.v. \\
\hline $\mathrm{Zn}$ & $\mathrm{mg} \mathrm{kg}^{-1}$ & 2 & $62(46)$ & $5.15(4.23)$ & 720 & 24600 & 2300 & 6.62 & 200 & 200 \\
\hline
\end{tabular}

DL: Detection limit; SD: Standard deviation; AR: Aqua regia digestion; DTPA: Diethylene-Triamine-Penta-Acetic acid extraction; n.d.: Not determined; n.v.: No value; * screening level refers only to avian and mammalian; EPA (RS): Residential soil regional screening level, EPA (P,A,M): Plant-Avian-Mammalian screening level, EPA (A,M): Avian-Mammalian screening level, CCME (A): Soil quality guideline for agricultural land use, CCME (R): Soil quality guideline for residential land use.

The most abundant element in the bulk sample of road sediment of the study area is $\mathrm{Ca}(17.4 \%)$ (Table 1$)$. The major elements content in the bulk sample of the examined road sediment from highest to lowest are: $\mathrm{Ca}(17.4 \%)>\mathrm{Mg}(3.35 \%)>\mathrm{Fe}(2.78 \%)>\mathrm{Al}$ $(0.82 \%)>\mathrm{K}(0.16 \%)>\mathrm{S}(0.11 \%)>\mathrm{Na}(0.08 \%)>\mathrm{Ti}(0.03 \%)$; while the decreasing order of elements concentration from highest to lowest are: $\mathrm{P}>\mathrm{Mn}>\mathrm{Zn}>\mathrm{Ni}>\mathrm{Cr}>\mathrm{Ba}>\mathrm{Sr}>\mathrm{Cu}$ $>\mathrm{Pb}>\mathrm{V}>\mathrm{Co}>\mathrm{B}>\mathrm{La}>\mathrm{As}>\mathrm{Sb}>\mathrm{Sc}>\mathrm{Cd}>$ Be (Table 1). Al-Taani et al. [45] reported median concentration of elements in road sediment samples gathered from Abu-Dhabi Al-Ain National Highway (UAE) as follows: Cr $\left(85 \mathrm{mg} \mathrm{kg}^{-1}\right), \mathrm{Mn}\left(850 \mathrm{mg} \mathrm{kg}^{-1}\right), \mathrm{Pb}$ $\left(10 \mathrm{mg} \mathrm{kg}^{-1}\right)$, and $\mathrm{Zn}\left(175 \mathrm{mg} \mathrm{kg}^{-1}\right)$. Cadmium and $\mathrm{Zn}$ can also be attributed to galvanized crash barriers and road signs [46]. Adamiec et al. [30] analyzed heavy metal concentration in bulk sediment samples of motorways in Katowice (Poland) and found the following order: $\mathrm{Fe}(4.2 \%)>\mathrm{Ti}(0.2 \%)>\mathrm{Zn}\left(1420 \mathrm{mg} \mathrm{kg}^{-1}\right)>\mathrm{Pb}\left(321 \mathrm{mg} \mathrm{kg}^{-1}\right)>\mathrm{Cr}\left(232 \mathrm{mg} \mathrm{kg}^{-1}\right)$ 
$>\mathrm{Cu}\left(198 \mathrm{mg} \mathrm{kg}^{-1}\right)>\mathrm{Sr}\left(119 \mathrm{mg} \mathrm{kg}^{-1}\right)>\mathrm{Ba}\left(114 \mathrm{mg} \mathrm{kg}^{-1}\right)>\mathrm{Ni}\left(62.3 \mathrm{mg} \mathrm{kg}^{-1}\right)$, and $\mathrm{Cd}\left(0.45 \mathrm{mg} \mathrm{kg}^{-1}\right)$. Concentration of $\mathrm{Cu}, \mathrm{Fe}, \mathrm{Pb}$, and $\mathrm{Zn}$, the well-known key tracers of traffic emissions [30,47-50], were higher in road sediment samples collected in Poland than in road sediment samples gathered in the study area. In fact, any comparison between elements content in road sediments collected in different regions tend to be very convoluted because the contribution of automobile emission on the composition of road sediment is controlled by various factors, as those reported by Werkenthin et al. [51] which are the following: Wind direction, wind velocity, geomorphological position of the road, types of fuel used, driving behavior, and previous dry periods.

The decreasing order of median content of major elements in bulk sample of car ash is: $\mathrm{Ca}(14.00 \%)>\mathrm{Mg}(9.98 \%)>\mathrm{Al}(1.83 \%)>\mathrm{Fe}(1.37 \%)>\mathrm{S}(0.26 \%)>\mathrm{K}(0.09 \%)>\mathrm{Ti}(0.06 \%)$ $>\mathrm{Na}(0.04 \%)$ (Table 1). Other elements that followed were in order: $\mathrm{Zn}>\mathrm{Cu}>\mathrm{Ba}>\mathrm{P}>\mathrm{Mn}$ $>\mathrm{Co}>\mathrm{Pb}>\mathrm{Sr}>\mathrm{Ni}>\mathrm{Cr}>\mathrm{Cd}>\mathrm{B}>\mathrm{La}>\mathrm{Sb}>\mathrm{V}>\mathrm{As}>\mathrm{Sc}>\mathrm{Be}$ (Table 1). A similar order of elements was identified by Apeagyei et al. [47] in brake pads dust, which is as follows: $\mathrm{Mn}>\mathrm{Zn}>\mathrm{Pb}>\mathrm{Cr}>\mathrm{Cd}$. The only difference between the two above mentioned orders is about the elements $\mathrm{Zn}$ and $\mathrm{Mn}$, which can be explained by the origin of the analyzed media. The examined bulk sample of car ash of the study area has consisted mostly of ash derived by tires, which are rich in $\mathrm{Zn}$, and secondly of ash derived from brake pads. Moreover, Apeagyei et al. [47] found that the most abundant element in tires was Zn; while $\mathrm{Cr}$ and $\mathrm{Pb}$ were also detected. According to Wiseman et al. [44], tires are an important $\mathrm{Sb}$ source since they contain this element in notable amounts. Moreover, brake linings have also been identified as a source of $\mathrm{Cd}, \mathrm{Cr}, \mathrm{Ni}$ and $\mathrm{Sb}$ [44]. Heavy metals in wheel balance weight varied widely from $0.35 \%, 2-20 \%, 75-95 \%$, and $3.4-4.2 \%$ for $\mathrm{As}, \mathrm{Fe}, \mathrm{Pb}$, and $\mathrm{Sb}$, respectively [52], suggesting that wheels are a major source of these elements in both car ash sample and road sediment sample of the study area.

\subsection{Distribution of the Elements in Topsoil, Road Sediment and Ash Samples}

Elevated content of aqua regia extracted $\mathrm{Cu}, \mathrm{Fe}, \mathrm{Mn}$, and $\mathrm{Zn}$ was observed in the topsoil of the sampling sites located directly at the curved section of Highways 1 and 2 (except only for Fe in Highway 2). The brake linings and tires are the most likely source of these metals' high content recorded in the road sediment (Figure 3a,c,d). Similar findings have also been reported by Wiseman et al. [44] in roadside soils in Toronto (Canada).

The highest value of DTPA extracted elements in topsoil were recorded for $\mathrm{Cu}$ (up to $2.6 \mathrm{mg} \mathrm{kg}^{-1}$ ), Fe (up to $0.004 \%$ ), Mn (up to $47.1 \mathrm{mg} \mathrm{kg}^{-1}$ ), and $\mathrm{Zn}$ (up to $15.7 \mathrm{mg} \mathrm{kg}^{-1}$ ), mainly related to traffic emission exhibited elevated content at the sampling sites close to the highway road (Figure 3a-d). Moreover, Wuana and Okieimen [28] suggested that DTPA extracted elements are mainly attributed to anthropogenic sources (e.g., traffic emissions). Spatial distribution maps (Figure 3a-d) present a higher accumulation of $\mathrm{Cu}_{\text {DTPA }}, \mathrm{Fe}_{\mathrm{DTPA}}$, $\mathrm{Mn}_{\mathrm{DTPA}}$, and $\mathrm{Zn}_{\mathrm{DTPA}}$ towards the northwestern than the eastern part of the area studied. The dominant winds in the area studied are from the WNW direction, which means that pollutants are carried away mainly northwest of Highways 1 and 2. Wind primarily flows from the WNW direction (from the Saronic gulf) and moves across the study area towards the Geraneia mountain (Figures 1 and 2).

The highest concentration of $\mathrm{Mn}$ was found in the bulk sample of road sediment; while in the topsoil in the highway's vicinity, the Mn content ranges from 287 to $531 \mathrm{mg}$ $\mathrm{kg}^{-1}$ (Figure 3c). The bulk sample of road sediment presented high Mn $\left(947 \mathrm{mg} \mathrm{kg}^{-1}\right)$ and $\mathrm{Zn}\left(720 \mathrm{mg} \mathrm{kg}^{-1}\right)$ concentration (Figure $\left.3 \mathrm{c}, \mathrm{d}\right)$. The high content of $\mathrm{Mn}$ in road sediment at the sampling site, which is located at the straight section of Highway 1 (Figure 3c), can be explained by the higher rate of exhaust emissions which increases at high automobile speeds. A similar explanation is given for the high $\mathrm{Zn}$ content at the road sediment collected at the same sampling site (Figure 3d) since vehicle tires' wear rate also increases at high speeds. The primary sources of $\mathrm{Mn}$ in the bulk sample of road sediment of the study area can be attributed to the use of gasoline by automobiles and the effect of soil aeolian erosion. Manganese compounds used as anti-knock additives to gasoline have 
now replaced $\mathrm{Pb}$ compounds [53]. According to Schlesinger [54], all the elements which are present in automobile fuel are emitted in the exhaust. These elements are distributed in the atmosphere as particles adsorbed onto surfaces of other particles or individual particles [38]. Titanium is a well-recognized key tracer of brake wear emissions since its concentration in brake lining is up to $2.5 \%$ [30]. The elevated concentration of Ti recorded in the bulk sample of road sediment $(0.03 \%)$, and its median content $(0.01 \%)$ in the study area's topsoil suggests an anthropogenic origin of this element.
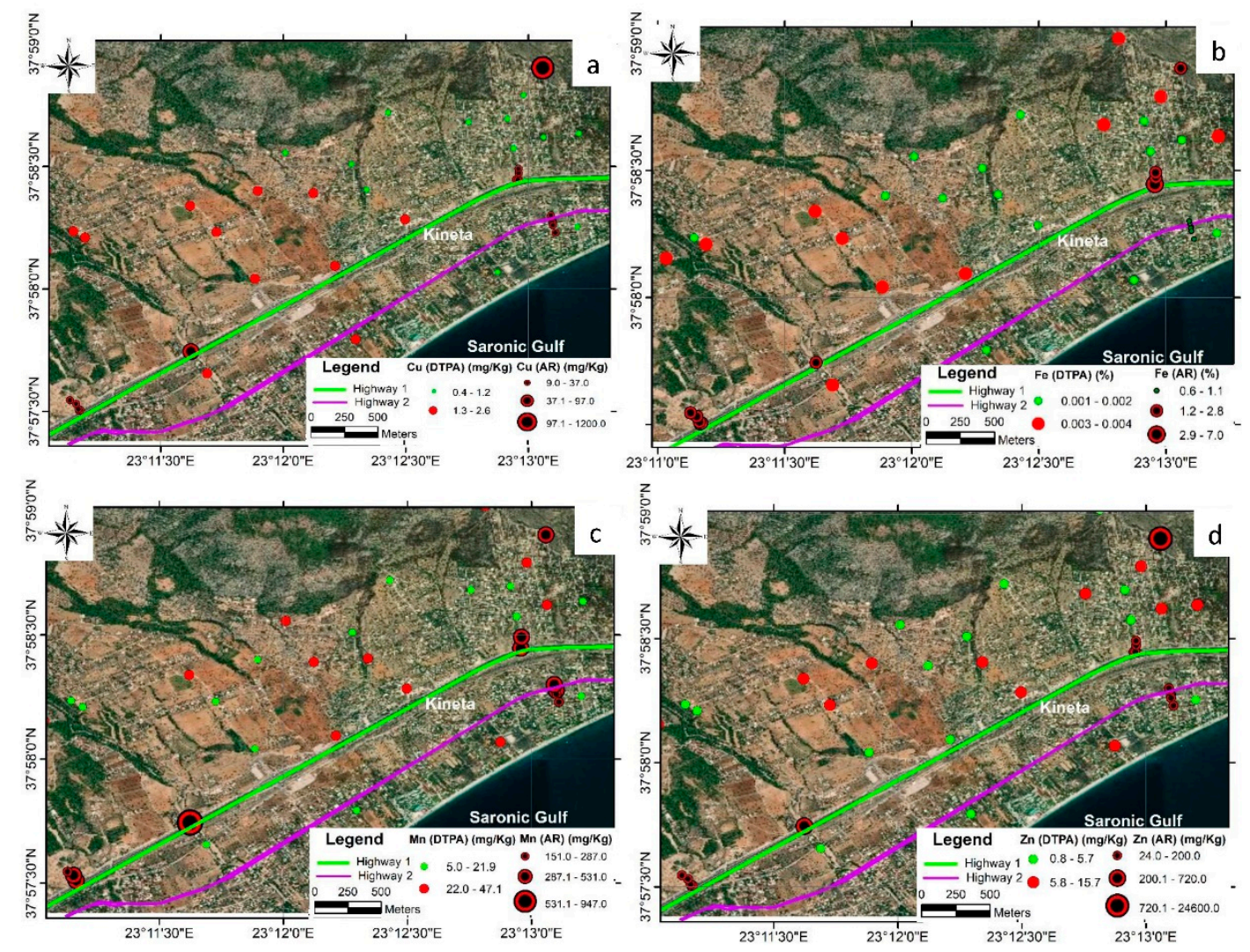

Figure 3. Graduated symbol plots of: (a) $\mathrm{Cu}$; (b) Fe; (c) Mn; and (d) Zn content in the topsoil of the study area. (AR: Aqua regia digestion; DTPA: Diethylene-Triamine-Penta-Acetic acid extraction).

\subsection{Evaluation of Contaminated Land in the Margin of Highways}

A comparison between the element's content of samples collected at the area studied and the corresponding screening level and criteria were given by the literature are shown in Table 1. For topsoil samples S1-S16 (aqua regia treated samples), the median content of $\mathrm{Al}, \mathrm{As}, \mathrm{B}, \mathrm{Ba}, \mathrm{Cd}, \mathrm{Co}, \mathrm{Cr}, \mathrm{Cu}, \mathrm{Fe}, \mathrm{Mn}, \mathrm{Ni}, \mathrm{Sb}, \mathrm{V}$, and $\mathrm{Zn}$ exceeds at least one of the screening levels and soil quality guidelines given by the literature (Table 1). The median value of $\mathrm{Cu}, \mathrm{Fe}, \mathrm{Mn}$, and $\mathrm{Zn}$ for the topsoil samples S17-S42 (DTPA treated samples) are lower than those of the criteria proposed by the literature (Table 1). The median value of topsoil samples S1 to S16 for As exceed the EPA (RS, PAM) screening level and CCME (A,R) soil quality guideline. Based on these findings, it is concluded that topsoil, known to contain element content higher than the corresponding critical level given from the literature, may pose a threat to plant species of the study area.

The obtained $\mathrm{I}_{\text {geo }}$ values for $\mathrm{Al}, \mathrm{Ba}, \mathrm{Be}, \mathrm{B}, \mathrm{K}, \mathrm{Na}, \mathrm{S}, \mathrm{Sc}, \mathrm{Ti}$, and $\mathrm{V}$ revealed that all examined samples in the Kineta area are practically uncontaminated, suggesting less anthropogenic influences. The spatial distribution of $\mathrm{I}_{\text {geo }}$ values for $\mathrm{As}, \mathrm{Cu}, \mathrm{Mn}, \mathrm{Ni}, \mathrm{P}, \mathrm{Pb}$, and $\mathrm{Zn}$ show more contaminated sites $\left(1<\mathrm{I}_{\text {geo }}<19\right)$ surrounding the Highways 1 and 2 (Figure $4 \mathrm{a}, \mathrm{c}-\mathrm{h}$ ). The highest enrichment in topsoils was recorded for $\mathrm{As}, \mathrm{Cu}, \mathrm{Mn}, \mathrm{Ni}, \mathrm{P}$, 
$\mathrm{Pb}$, and $\mathrm{Zn}$, mainly related to traffic emissions exhibited high $\mathrm{I}_{\text {geo }}$ values in the margins of highways of the study area (Figure $4 \mathrm{a}, \mathrm{c}-\mathrm{h}$ ).
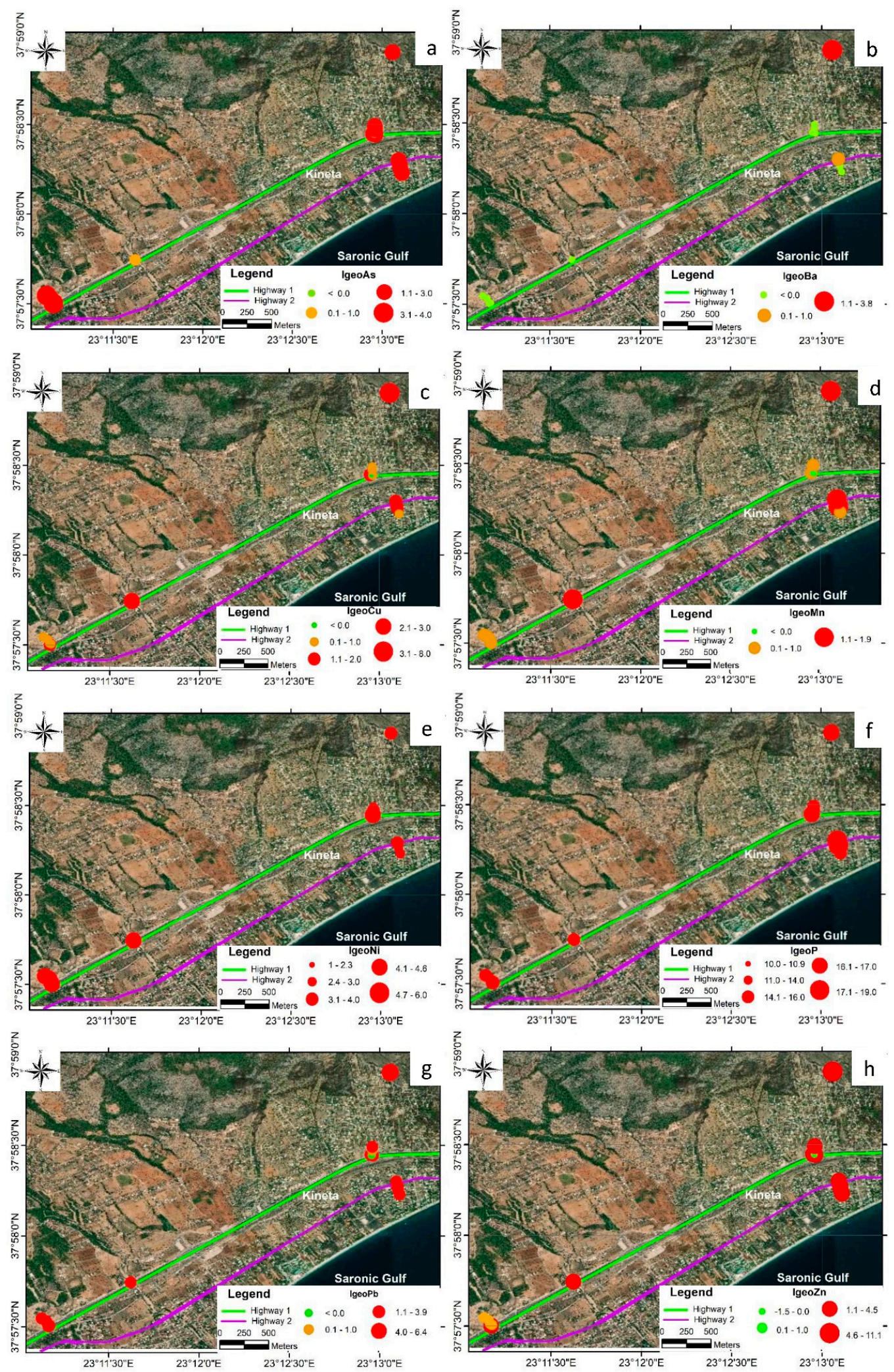

Figure 4. Spatial distribution of $\mathrm{I}_{\text {geo }}$ for: (a) Arsenic (As); (b) barium (Ba); (c) copper (Cu); (d) manganese (Mn); (e) nickel $(\mathrm{Ni}) ;(\mathbf{f})$ phosphorous $(\mathrm{P}) ;(\mathrm{g})$ lead $(\mathrm{Pb})$; and $(\mathbf{h})$ zinc $(\mathrm{Zn})$. 
The $\mathrm{I}_{\text {geo }}$ values for As and Ba lower than 1 are observed in the bulk sample of road sediment, which can be explained by the short accumulation time (7 days) of road sediments. The Igeo values for $\mathrm{Cu}, \mathrm{Mn}, \mathrm{Ni}, \mathrm{P}, \mathrm{Pb}$, and $\mathrm{Zn}$ observed in the bulk sample of road sediment are higher than 1 , denoting moderately contaminated to extremely contaminated sites. According to Aravelli and Heibel [48], the composition of ash accumulated in the filter of a vehicle engine is the following: $\mathrm{Ba}$ (up to $1 \mathrm{mg} \mathrm{kg}^{-1}$ ), $\mathrm{Cu}$ (up to $1 \mathrm{mg} \mathrm{kg}^{-1}$ ), Mn (up to $1 \mathrm{mg} \mathrm{kg}^{-1}$ ), P (up to $1273 \mathrm{mg} \mathrm{kg}^{-1}$ ), and Zn (up to $1421 \mathrm{mg} \mathrm{kg}^{-1}$ ), suggesting a common source of these elements in the bulk sample of road sediment of the study area. Additionally, As and Mn content in road sediment are commonly ascribed to brake abrasion dust and power plant fly ash [55]. Dousova et al. [55] reported that $\mathrm{AsO}_{3}$ and $\mathrm{MnO}$ content in brake abrasion dust is up to 0.01 and $0.5 \% \mathrm{wt}$, respectively, while $\mathrm{AsO}_{3}$ and $\mathrm{MnO}$ content in powerplant fly ash is up to 1.6 and $0.1 \% \mathrm{wt}$, respectively.

Elevated Igeo values for $\mathrm{Ni}$ (up to 6.0), P (up to 19.0), and $\mathrm{Zn}$ (up to 11.1) are observed in the topsoil of sampling sites scattered over the area, which may be attributed to traffic emissions. The distribution of $\mathrm{I}_{\text {geo }}$ values for $\mathrm{Ni}, \mathrm{P}$, and $\mathrm{Zn}$ present high spatial correlation and needs further discussion (Figure 4e,f,h). Nickel level in various crude oil ranges from 8 to $296 \mathrm{mg} \mathrm{kg}^{-1}$ [56]. Zinc dialkyl-dithio-phosphate $\left(\mathrm{Zn}\left[\left(\mathrm{S}_{2} \mathrm{P}(\mathrm{OR})_{2}\right]_{2}\right.\right.$, where $\mathrm{R}$ is a branched or linear alkyl between 1-14 carbons in length) is used almost universally in engine oils as an anti-wear agent additive and anti-oxidant [49]. Phosphorous, which is added as a lubricant additive in motor oils, reaches the catalyst as phosphorous oxide vapour and metal phosphate particulates [49]. Selby et al. [57] recorded $P$ emissions on exhaust catalyst up to 761 and $43 \mathrm{mg} \mathrm{L}^{-1}$ for fresh oil and volatilized oil, respectively. Phosphorous and $\mathrm{Zn}$ content in ash accumulated in the filter of vehicle engines are up to 1273 and $1421 \mathrm{mg} \mathrm{kg}^{-1}$, respectively, suggesting a common origin, fate, and transport of these elements from motor engines to the highways [48]. The literature data, the distribution of high $\mathrm{I}_{\text {geo }}$ values in the proximity of highways, as well as the spatial correlation of $\mathrm{I}_{\text {geo }}$ values for $\mathrm{Ni}, \mathrm{P}$, and $\mathrm{Zn}$, suggests the common source of these elements, which is the combustion products of motor fuels. In the study area, the transport mechanism for dust containing $\mathrm{Ni}, \mathrm{P}$, and $\mathrm{Zn}$ from highways to the land of the immediate neighborhood of motorways, also involves the dominant wind direction, which is from the seaside.

Similar findings regarding the successful application of $I_{\text {geo }}$ for evaluating the element distribution in the adjacent land of motorways have also been reported by Adamiec et al. [30]. Adamiec et al. [30] applied $I_{\text {geo }}$ index to quantify heavy metal contamination in urban and motorway road sediments of Zagreb (Croatia). The $\mathrm{I}_{\text {geo }}$ index for road sediments of Zagreb revealed that the examined sites are extremely contaminated for $\mathrm{Cu}, \mathrm{Cr}$, and $\mathrm{Ti}$ and strongly contaminated for $\mathrm{Zn}, \mathrm{Ni}$, and $\mathrm{Pb}$; while the sites are not contaminated with $\mathrm{Cd}[30]$.

For bulk sample of road sediment, the median content of $\mathrm{Mn}, \mathrm{Ni}, \mathrm{Sb}$, and $\mathrm{V}$ is higher than all the corresponding criteria proposed by the literature (Table 1). Diesel fuel and lubricating oil are considered sources of particular importance for $\mathrm{Ni}$ [58]. Nickel and $\mathrm{V}$ are the leading indicators of emissions from incomplete combustion products [7]. Antimony present in the particles formed because of brake pad wear [7,55]. Furthermore, in localities exposed to the release of $\mathrm{Sb}$ during the braking process, the $\mathrm{Sb}$ concentration exceeded up to 60 times the background value [59]. Organic $\mathrm{Sb}$ compounds are used as additives in oil and grease [60]. Manganese and $\mathrm{Zn}$ have been classified as being part of brake pads $[47,50]$. Fujiwara et al. [59] reported that $\mathrm{Mn}$ is applied as an anti-knock additive in motor vehicle fuels. The high content of $\mathrm{Mn}$ and $\mathrm{Zn}$ are linked to neurodegenerative diseases, such as Alzheimer and Parkinson diseases [61], and can pose a severe threat to the ecosystems [62-64].

\section{Conclusions}

The concentration of $\mathrm{As}, \mathrm{Cu}, \mathrm{Mn}, \mathrm{Ni}, \mathrm{P}, \mathrm{Pb}$, and $\mathrm{Zn}$ in topsoil in the highway's margin appeared to be influenced by traffic emissions. The brake linings and tires are the most likely anthropogenic source of the high content of $\mathrm{Cu}, \mathrm{Mn}$, and $\mathrm{Zn}$ in the topsoil of the 
sampling sites, located directly at the curved section of the highways of the study area. The spatial analysis of the $\mathrm{Cu}_{\mathrm{DTPA}}, \mathrm{Fe}_{\mathrm{DTPA}}, \mathrm{Mn}_{\mathrm{DTPA}}$, and $\mathrm{Zn}_{\mathrm{DTPA}}$ contents in topsoil showed that the accumulation of $\mathrm{Cu}_{\text {DTPA }}, \mathrm{Fe}_{\mathrm{DTPA}}, \mathrm{Mn}_{\mathrm{DTPA}}$, and $\mathrm{Zn}_{\mathrm{DTPA}}$ in sampling sites towards the northwestern part is higher than the accumulation of these elements in sampling sites located in the eastern part of the area studied. The $\mathrm{I}_{\text {geo }}$ classification indicated that topsoil is moderately to heavily contaminated with As and $\mathrm{Ba}$, moderately to heavily/extremely contaminated with $\mathrm{Cu}$ and $\mathrm{Ni}$, moderately to extremely contaminated with $\mathrm{Pb}$ and $\mathrm{Zn}$. The $\mathrm{I}_{\text {geo }}$ values for topsoil denoted moderate Mn contamination and extreme P contamination. It is found that engine exhaust, tire wear, and wear of brake lining contribute to the As, $\mathrm{Ba}, \mathrm{Cu}, \mathrm{Mn}, \mathrm{Ni}, \mathrm{P}, \mathrm{Pb}$, and $\mathrm{Zn}$ content recorded in the soil in the margin of highways of the area studied. It should not be neglected that a possible additional $\mathrm{Pb}$ source in the topsoil of the study area is its past use as an additive to gasoline. Highways in the Kineta area are sources of soil contaminants due to exhaust and non-exhaust vehicular emissions. Suburban soils of the Kineta area are acting as a sink for metals originating from traffic emissions. The transport of contaminants over the suburban area of Kineta depended partly on regional-scale wind flows from the Saronic Gulf. The $I_{\text {geo }}$ values revealed that the bulk sample of road sediment is moderately contaminated to extremely contaminated with $\mathrm{Cu}, \mathrm{Mn}, \mathrm{Ni}, \mathrm{P}, \mathrm{Pb}$, and $\mathrm{Zn}$. The $\mathrm{I}_{\text {geo }}$ index results provide a successful tool for monitoring the area by repeating the research within several years. Comparison of element content in topsoil with criteria established by the literature revealed that $\mathrm{Al}, \mathrm{As}, \mathrm{B}, \mathrm{Ba}, \mathrm{Cd}, \mathrm{Co}, \mathrm{Cr}, \mathrm{Cu}$, $\mathrm{Fe}, \mathrm{Mn}, \mathrm{Ni}, \mathrm{Sb}, \mathrm{V}$, and $\mathrm{Zn}$ pose a potential risk for plants. It is crucial to conduct further research studies on monitoring these contaminants, which help estimate risks of traffic for near-road populations and identify any potential impacts of traffic emissions on human health and ecological receptors.

Supplementary Materials: The following is available online at https:/ / www.mdpi.com/2073-445 $\mathrm{X} / 10 / 3 / 230 / \mathrm{s} 1$, burned car found in the study area and locations $(1,2,3,4,5,6)$ of the sub-samples of car ash.

Funding: This research received no external funding.

Institutional Review Board Statement: Not applicable.

Informed Consent Statement: Not applicable.

Data Availability Statement: Data is contained within the article.

Conflicts of Interest: The author declares no conflict of interest.

\section{References}

1. Potarzycki, J.; Grzebisz, W.; Biber, M.; Diatta, J.B. Stan geochemiczny gleb i jakosc plodow rolnych w strefie oddzialywania trasy komunikacyjnej Poznan-Swiecko. Rocz. AR. Pozn., CCCX Melior. Inz. Srodow. 1999, 20, 77-85.

2. Szyszlak-Barglowicz, J.; Slowik, T.; Zajac, G.; Piekarski, W. Metale ciêzkie w rowach odwadniajacych ciagów komunikacyjnych. Rocznik Ochrona OErodowiska 2013, 15, 2309-2323.

3. Komorowski, A.; Szulc, W. Impact of traffic routes on the content of trace elements in soils in Warsaw agglomeration. Soil Sci. Annu. 2017, 68, 87-92. [CrossRef]

4. Li, Y.; Yu, Y.; Yang, Z.; Shen, Z.; Wang, X.; Cai, Y. A comparison of metal distribution in surface dust and soil among super city, town, and rural area. Environ. Sci. Pollut. Res. Int. 2016, 23, 7849-7860. [CrossRef] [PubMed]

5. Kang, J.; Lee, S.W.; Cho, K.H.; Ki, S.J.; Cha, S.M.; Kim, J.H. Linking land use type and stream water quality using spatial data of fecal indicator bacteria and heavy metals in the Yeongsan river basin. Water Res. 2010, 44, 4143-4157. [CrossRef] [PubMed]

6. Xu, G.; Liu, J.; Pei, S.; Kong, X.; Hu, G. Distribution and source of heavy metals in the surface sediments from the near-shore area, north Jiangsu Province, China. Mar. Pollut. Bull. 2014, 83, 275-281. [CrossRef]

7. Cabral Pinto, M.M.S.; Ferreira da Silva, E.A. Heavy metals of Santiago island (Cape Verde) alluvial deposits: Baseline value maps and human health risk assessment. Int. J. Environ. Res. Pub. Health 2019, 16, 2. [CrossRef] [PubMed]

8. Cabral Pinto, M.M.S.; Ferreira da Silva, E.A.; Silva, M.M.V.G.; Melo-Gonçalves, P.; Candeias, C. Environmental risk assessment based on high-resolution spatial maps of potentially toxic elements sampled on stream sediments of Santiago, Cape Verde. Geosciences 2014, 4, 297-315. [CrossRef] 
9. Cabral Pinto, M.M.S.; Inácio, M.; Orquidia Neves, M.; Almeida, A.; Pinto, E.; Oliveiros, B.; Ferreira da Silva, E.A. Human health risk assessment due to agricultural activities and crop consumption in the surroundings of an industrial area. Expo. Health 2020, 12, 629-640. [CrossRef]

10. Cabral Pinto, M.M.S.; Silva, M.M.V.G.; Ferreira da Silva, E.A.; Dinis, P.A.; Rocha, F. Transfer processes of potentially toxic elements (PTE) from rocks to soils and the origin of PTE in soils: A case study on the island of Santiago (Cape Verde). J. Geochem. Explor. 2017, 183, 140-151. [CrossRef]

11. Ermolin, M.S.; Fedotov, P.S.; Ivaneev, A.I.; Karandashev, V.K.; Fedyunina, N.N.; Eskina, V.V. Isolation and quantitative analysis of road dust nanoparticles. J. Anal. Chem. 2017, 72, 520-532. [CrossRef]

12. Hong, N.; Guan, Y.; Yang, B.; Zhong, J.; Zhu, P.; Sik Ok, Y.; Hou, D.; Tsang, D.C.W.; Guan, Y.; Liu, A. Quantitative source tracking of heavy metals contained in urban road deposited sediments. J. Hazard. Mater. 2020, 393, 122362. [CrossRef]

13. Padoan, E.; Romè, C.; Ajmone-Marsan, F. Bioaccessibility and size distribution of metals in road dust and roadside soils along a peri-urban transect. Sci. Total Environ. 2017, 601, 89-98. [CrossRef]

14. Alexakis, D.; Kokmotos, I.; Gamvroula, D.; Varelidis, G. Wildfire effects on soil quality: Application on a suburban area of West Attica (Greece). Geosci. J. 2020. [CrossRef]

15. Alexakis, D. Suburban areas in flames: Dispersion of potentially toxic elements from burned vegetation and buildings. Estimation of the associated ecological and human health risk. Environ. Res. 2020, 183, 109153. [CrossRef] [PubMed]

16. Antoniou, M.; Archontidis, A.; Breton, F.; Kazatzopoulos, G.; Keladinos, T.; Korombili, E.; Malavakis, T.; Papakostas, K.; Paterakis, G.; Stamou, S. The 2018 Sustainable Development Report of OLYMPIA ODOS S.A. 2018. Available online: https://www. olympiaodos.gr/images/user/aiforos_anaptyxi/Ekthesi_Aeiforou_Anaptyksis_Olympia_Odos_2018_ENG_p.pdf (accessed on 20 December 2020).

17. Alexakis, D. Human health risk assessment associated with $\mathrm{Co}, \mathrm{Cr}, \mathrm{Mn}, \mathrm{Ni}$ and $\mathrm{V}$ content in agricultural soils from a Mediterranean site. Arch. Agron. Soil Sci. 2016, 62, 359-373. [CrossRef]

18. Alexakis, D.; Gamvroula, D.; Theofili, E. Environmental availability of potentially toxic elements in an agricultural Mediterranean site. Environ. Eng. Geosci. 2019, 25, 169-178. [CrossRef]

19. Gaitanakis, P.; Mettos, A.; Fytikas, M.; Tsaila-Monopolis, S.; Tsapralis, V.; Ioakim, C.; Katsikatsos, C. Geological Map of Greece Sofikon Sheet (1:50.000); Institute of Geology and Mineral Exploration: Athens, Greece, 1985.

20. Gamvroula, D.; Alexakis, D.; Stamatis, G. Diagnosis of groundwater quality and assessment of contamination sources in the Megara basin (Attica, Greece). Arab. J. Geosci. 2013, 6, 2367-2381. [CrossRef]

21. Kaplanis, A.; Koukouvelas, I.; Xypolias, P.; Kokkalas, S. Kinematics and ophiolite obduction in the Gerania and Helicon Mountains, central Greece. Tectonophysics 2013, 596, 215-234. [CrossRef]

22. NOA-National Observatory of Athens. Monthly Climatological Summary. National Observatory of Athens. 2019. Available online: http:/ / meteosearch.meteo.gr/data/agioitheodoroi/2019-10.txt (accessed on 28 December 2020).

23. NOA-National Observatory of Athens. Annual Climatological Summary. National Observatory of Athens. 2019. Available online: http:/ / penteli.meteo.gr/stations/agioitheodoroi/NOAAPRYR.TXT (accessed on 28 December 2020).

24. Alexakis, D. Contaminated land by wildfire effect on ultramafic soil and associated human health and ecological risk. Land 2020, 9, 409. [CrossRef]

25. Dai, J.; Becquer, T.; Rouiller, J.H.; Reversat, G.; Bernhard-Reversat, F.; Nahmani, J.; Lavelle, P. Heavy metal accumulation by two earthworm species and its relationship to total and DTPA extractable metals in soils. Soil Biol. Biochem. 2004, 36, 91-98. [CrossRef]

26. Feng, M.H.; Shan, X.Q.; Zhang, S.; Wen, B. A comparison of the rhizosphere-based method with DTPA, EDTA, CaCl 2 , and NaNO 3 extraction methods for prediction of bioavailability of metals in soil to barley. Environ. Pollut. 2005, 137, 231-240. [CrossRef]

27. Maiz, I.; Arambarri, I.; Garcia, R.; Millán, E. Evaluation of heavy metal availability in polluted soils by two sequential extraction procedures using factor analysis. Environ. Pollut. 2000, 110, 3-9. [CrossRef]

28. Wuana, R.A.; Okieimen, F.E. Heavy metals in contaminated soils: A review of sources, chemistry, risks and best available strategies for remediation. Int. Schol. Res. Net. Ecol. 2011, 2011, 402647. [CrossRef]

29. Muller, G. Schwermetalle in den Sedimenten des Rheins-Veranderungen seit 1971. Umschau 1979, 79, 778-783.

30. Adamiec, E.; Jarosz-Krzemińska, E.; Wieszała, R. Heavy metals from non-exhaust vehicle emissions in urban and motorway road dusts. Environ. Monit. Assess. 2016, 188, 369. [CrossRef]

31. Rozanski, S.; Jaworska, H.; Matuszczak, K.; Nowak, J. Impact of highway traffic and the acoustic screen on the content and spatial distribution of heavy metals in soils. Envron. Sci. Pollut. Res. 2017, 24, 12778-12786. [CrossRef]

32. Elnazer, A.A.; Salman, S.A.; Seleem, E.M.; Abu El Ella, E.M. Assessment of some heavy metals pollution and bioavailability in roadside soil of Alexandria-Marsa Matruh highway, Egypt. Int. J. Ecol. 2015, 2015, 689420. [CrossRef]

33. Kim, B.S.M.; Friedmann Angeli, J.L.; Lima Ferreira, P.L.; Mahiques, M.M.; Lopes Figueira, R.C. Critical evaluation of different methods to calculate the Geoaccumulation Index for environmental studies: A new approach for Baixada Santista-Southeastern Brazil. Mar. Pollut. Bull. 2018, 127, 548-552. [CrossRef] [PubMed]

34. Jiang, J.; Wang, J.; Liu, S.; Lin, C.; He, M.; Liu, X. Background, baseline, normalization, and contamination of heavy metals in the Liao River watershed sediments of China. J. Asian Earth Sci. 2013, 73, 87-94. [CrossRef]

35. Alexakis, D. Diagnosis of stream sediment quality and assessment of toxic element contamination sources in East Attica, Greece. Environ. Earth Sci. 2011, 63, 1369-1383. [CrossRef] 
36. Kumar, A.; Cabral-Pinto, M.; Kumar, A.; Kumar, M.; Dinis, P.A. Estimation of risk to the eco-environment and human health of using heavy metals in the Uttarakhand Himalaya, India. Appl. Sci. 2020, 10, 7078. [CrossRef]

37. Turekian, K.K.; Wedepohl, K.H. Distribution of the elements in some major units of the Earth's crust. Geol. Soc. Am. Bull. 1961, 72, 175-192. [CrossRef]

38. EPA (Environmental Protection Agency) Cleanup Regulations and Standards. Available online: http:/ / www.epa.gov/cleanup/ regs.htm (accessed on 17 December 2020).

39. CCME (Canadian Council of Ministers of the Environment). Available online: http://st-ts.ccme.ca/en/index.html (accessed on 24 January 2020).

40. Salminen, R.; Batista, M.J.; Bidovec, M.; Demetriades, A.; De Vivo, B.; De Vos, W.; Duris, M.; Gilucis, A.; Gregorauskiene, V.; Halamic, J.; et al. FOREGS Geochemical Atlas of Europe Part 1. Background Information, Methodology and Maps. Geological Survey of Finland, Espoo. 2005. Available online: http:/ / weppi.gtk.fi/publ/foregsatlas/article.php?id=15 (accessed on 7 February 2021).

41. Davies, B.E. Lead. In Heavy Metals in Soils; Alloway, B.J., Ed.; Blackie and Son: Glasgow, UK, 1990; pp. $177-195$.

42. National Research Council. Fuels and Fuels Additives for Highway Vehicles and Their Combustion Products: A Guide to Evaluation of Their Potential Effect on Health; The National Academies Press: Washington, DC, USA, 1976.

43. Romic, M.; Romic, D. Heavy metals distribution in agricultural topsoils in urban area. Environ. Geol. 2003, 43, 795-805. [CrossRef]

44. Wiseman, C.L.S.; Zereini, F.; Püttmann, W. Traffic-related trace element fate and uptake by plants cultivated in roadside soils in Toronto, Canada. Sci. Tot. Environ. 2013, 442, 86-95. [CrossRef]

45. Al-Taani, A.A.; Nazzal, Y.; Howari, F.M. Assessment of heavy metals in roadside dust along the Abu Dhabi-Al Ain National Highway, UAE. Environ. Earth Sci. 2019, 78, 411. [CrossRef]

46. Kluge, B.; Wessolek, G. Heavy metal deposition and soil concentration in soils along the oldest highway of the world-The AVUS autobahn. Environ. Monit. Assess. 2012, 184, 6469-6481. [CrossRef] [PubMed]

47. Apeagyei, E.; Bank, M.S.; Spengler, J.D. Distribution of heavy metals in road dust along an urban-rural gradient in Massachusetts. Atmos. Environ. 2011, 45, 2310-2323. [CrossRef]

48. Aravelli, K.; Heibel, A. Improved lifetime pressure drop management for robust cordierite (RC) filters with asymmetric cell technology (ACT). SAE Tech. Pap. Ser. 2007, 1, 920.

49. Spikes, H. Low- and zero-sulphated ash, phosphorus and sulphur anti-wear additives for engine oils. Lubric. Sci. 2008, 20, 103-136. [CrossRef]

50. Straffelini, G.; Ciudin, R.; Ciotti, A.; Gialanella, S. Present knowledge and perspectives on the role of copper in brake materials and related environmental issues: A critical assessment. Environ. Pollut. 2015, 207, 211-219. [CrossRef]

51. Werkenthin, M.; Kluge, B.; Wessolek, G. Metals in European roadside soils and soil solution-A review. Environ. Pollut. 2014, 189, 98-110. [CrossRef]

52. Plombco Inc. Material Safety Data Sheet. Lead Wheel Balance Weight. Available online: http://www.plombco.com/plombco/ wp-content/uploads/2015/07/FDS-Plombco-Masse-d\%C3\%A9quilibrage-en-plomb-EN.pdf (accessed on 29 December 2020).

53. Graedel, T.E. Ambient levels of anthropogenic emissions and their atmospheric transformation products. In Air Pollution, the Automobile, and Public Health; Watson, A.T., Bates, R.R., Kennedy, D., Eds.; National Academy Press: Washington, DC, USA, 1988.

54. Schlesinger, R.B. Biological disposition of airborne particles: Basic principles and application to vehicular emissions. In Air Pollution, the Automobile, and Public Health; Watson, A.T., Bates, R.R., Kennedy, D., Eds.; National Academy Press: Washington, DC, USA, 1988.

55. Dousova, B.; Lhotka, M.; Buzek, F.; Cejkova, B.; Jackova, I.; Bednar, V.; Hajek, P. Environmental interaction of antimony and arsenic near busy traffic nodes. Sci. Total Environ. 2020, 702, 134642. [CrossRef] [PubMed]

56. Reynolds, J.G. Nickel in petroleum refining. Petrol. Sci. Tech. 2001, 19, 979-1007.

57. Selby, T.W.; Bosch, R.J.; Fee, D.C. Phosphorous additive chemistry and its effects on the phosphorous volatility of engine oils. J. ASTM Int. 2005, 2, JAI12977. [CrossRef]

58. Thorkild Hvited, J.; Vollertsen, J.; Nielsen, A.H. Urban and Highway Stormwater Pollution: Concepts and Engineering; CRC Press, Taylor \& Francis Group: Boca Raton, FL, USA, 2010.

59. Ceriotti, G.; Amarasiriwardena, D. A study of antimony complexed to soil derived humic acids and inorganic antimony species along a Massachusetts highway. Microchem. J. 2009, 91, 85-93. [CrossRef]

60. Fujiwara, F.; Rebagliati, R.J.; Dawidowski, L.; Gómez, D.; Polla, G.; Pereyra, V.; Smichowski, P. Spatial and chemical patterns of size fractionated road dust collected in a megacity. Atmos. Environ. 2011, 45, 1497-1505. [CrossRef]

61. Cabral Pinto, M.M.S.; Marinho-Reis, A.P.; Almeida, A.; Freitas, S.; Simões, M.R.; Diniz, M.L.; Pinto, E.; Ramos, P.; Ferreira da Silva, E.A.; Moreira, P.I. Fingernail trace element content in environmentally exposed individuals and its influence on their cognitive status in ageing. Expo. Health 2019, 11, 181-194. [CrossRef]

62. Hoaghia, M.-A.; Levei, E.-A.; Cadar, O.; Senila, M.; Hognogi, G. Assessment of metal contamination and ecological risk in urban soils situated near a metallurgical complex. Environ. Eng. Manag. J. 2017, 16, 1623-1630. [CrossRef]

63. Cadar, O.; Miclean, M.; Cadar, S.; Tanaselia, C.; Senila, L.R.; Senila, M. Assessment of heavy metals in cow's milk in Rodnei mountains area, Romania. Environ. Eng. Manag. J. 2015, 14, 2523-2528. [CrossRef]

64. Neag, E.; Hoaghia, M.-A.; Torok, A.; Levei, E.; Senila, M.; Roman, C. Study of metals leaching from nonferrous mine tailings in organic and inorganic extractants. Int. J. Chem. Chem. Eng. Syst. 2018, 3, 42-49. 